\title{
Study of Soil, Water, and Cropping Pattern in Danastar Wah (Manchar Lake) Command Area Using Geospatial Tools
}

\author{
ALTAF ALI SIYAL*, IMRAN LAKHAIR**, MUHAMMAD MUNIR BABAR*, PIRAH SIYAL***, AND \\ GHULAM SHABIR SOLANGI*
}

RECEIVED ON 13.12.2017 ACCEPTED ON 12.02.2018

\begin{abstract}
The effluent water brought by RBOD (Right Bank Outfall Drain) is not only threat to the aquatic life of Manchar Lake but also the fertile agricultural lands which are being cultivated by use of lake water through Danastar Wah are at risk of salinization. The farming community of the area is scary of continual use of irrigation waters received through the Danastar Wah; they are of the view that the constant use of this water will ruin their fertile lands into salt-affected soils. Thus, keeping in view the fears of the farmers of the command area of Danastar Wah, a study was carried out to investigate the water quality of the Manchar Lake, RBOD MNV (Main Nara Valley) drain and Danastar Wah, and to examine soil salinity status of the area using Geo-referenced field and satellite imagery data for Kharif season of the year 2015. The results of the study showed that the EC (Electrical Conductivity) of the Danastar Wah water was below $1.2 \mathrm{dS} / \mathrm{m}$. Thus, the water was suitable for irrigation purpose. In all the water samples, $\mathrm{Na}^{+}, \mathrm{Ca}^{2+}+\mathrm{Mg}^{2+}$ and $\mathrm{CO}_{3}$ concentrations were found within the permissible limits, while no concentration of $\mathrm{HCO}_{3}$ was found in any of the water samples. In the command area, clay texture was dominant down to a depth of $60 \mathrm{~cm}$ soil profile. In the area about 37,28 , and $30 \%$ of the soils were normal (non-saline), saline and sodic, respectively; while only $5 \%$ of soils were saline-sodic. The cotton crop was identified as the major Kharif crop, occupying about $13.76 \%$ (2,844 ha) of the total command area, followed by rice crop grown on about $5.21 \%(1,078 \mathrm{ha})$ of the command area. The overall accuracy of image classification was $90 \%$ with a kappa coefficient of 0.86 . Based on this study, it can be concluded that the water of the Danastar Wah can be used for irrigation purpose during Kharif season only with the condition that adequate land drainage is maintained. It is also suggested that before using the water of Manchar Lake, RBOD and Danastar Wah for Rabi season, analysis for water quality be conducted. GeoInformatics (GIS and RS) tools can be employed for spatial and temporal monitoring of water quality of the Manchar Lake.
\end{abstract}

Key Words: Manchar Lake, Danastar Wah, Soil Texture, Salinity, Image Classification.

\section{INTRODUCTION}

anchar Lake is the most prominent natural shallow fresh water lake of Pakistan and South Asia [1]. The lake is situated in the southernmost province of the country, the Sindh, near the Sehwan city. It is located at a longitude of $67^{\circ} 31^{\prime} 32^{\prime \prime}$ E and $67^{\circ} 50^{\prime} 37^{\prime \prime} \mathrm{E}$ and latitude of $26^{\circ} 21^{\prime} 07^{\prime \prime} \mathrm{N}$ and $26^{\circ} 31^{\prime}$

Corresponding Author (E-Mail: aasiyal.uspcasw@faculty.muet.edu.pk, 5103160321@stmcid.ujs.edu.cn, mmunirbabar.uspcasw@faculty.muet.edu.pk,pirahaltaf@chemist.com, solangi_shabir@yahoo.com)

* US-Pakistan Center for Advanced Studies in Water, Mehran University of Engineering \& Technology, Jamshoro.

** School of Agricultural Equipment Engineering, Jiangsu University, China.

*** National Center of Excellence in Analytical Chemistry, University of Sindh, Jamshoro.

This is an open access article published by Mehran University Research Journal of Engineering and Technology, Jamshoro under the CC by 4.0 International License. 
$26 " \mathrm{~N}$ and at an altitude of 34.14 meters above the MSL. The lake is shallow having depth from 0.5-3.75 m. With the season, the area of the lake varies between 228-250 sq. $\mathrm{km}$. The lake is a natural depression but was brought under controlled conditions by putting embankments and installing sluice gate structures when the Sukkur Barrage was built in 1932. On western and southern rims of the lake lie Khirthar Mountains and Bhaga Tora hills, respectively; on the eastern edge of the lake lies river Indus, while on the northernside of the lake lies fertile plane land.

In the area, the lake has been one of the primary sources of irrigation waters since pre-Arian times. The irrigation water taken from the lake is conveyed through Danastar Wah and distributed through a network of smaller natural channels (phats) [2]. The Wah is an old flood canal. In 1972, on the demand of local farmers, the Wah was remodeled for a discharge capacity of 500 cusecs. Small pumping units are installed on the Wah and on phats to supplement irrigation water.

The lake, which was once said to be the largest freshwater lake in Asia, is now suffering from environmental degradation due to the outfall of effluent water by MNV drain into the lake and due to flabby methods of fishing and waste disposal by fisher. For the last few decades, the effluent water received from upper Sindh and Baluchistan is directly discharged into the lake [3]. That effluent water is not only threat to the aquatic life of the lake but also threat to flora and fauna activities. The fertile agricultural lands which are being irrigated by using the lake water are also at risk of degradation due to salinization.

For the last few decades, quality of the agricultural lands in the area and crop-yields have been declining continuously. Farmers are complaining that this untoward impact is due to using of poor quality water received from the Danastar Wah for irrigation purpose. They are of the view that their lands are converting from productive to non-productive salt-affected soils. So far, a limited study has been conducted on cropping pattern of the area, physicochemical properties of the land (soil) being irrigated and water quality of the Danaster Wah by using any modern technique. Presently, Geo-Informatics tools are the modern techniques that are widely used for soil and water mapping, assessment of cropping pattern and area for a wide range of scales and geographic locations [4-9]. Thus, keeping in view the concerns of farmers of the Danastar Wah command area about degradation of their agricultural lands, present study was envisaged to investigate the water quality of the Manchar Lake, RBOD, Danastar Wah and examine the physicochemical properties of the agricultural lands and any spatial variation in soil salinity using modern Geo-informatics tools.

\section{MATERIALS AND METHOD}

\subsection{Study Area}

The study area comprises of command area of the Danastar Wah. The area is located between longitude $67^{\circ}$ $37^{\prime} 33^{\prime \prime}$ and $67^{\circ} 51^{\prime} 20^{\prime \prime} \mathrm{E}$, and latitude $26^{\circ} 24^{\prime} 1^{\prime \prime}$ and $26^{\circ} 33^{\prime}$ $47 " \mathrm{~N}$ at an altitude of about $36 \mathrm{~m}$ above the MSL. The Danastar Wah, is an inundation canal, which originates from the Manchar Lake at longitude of $67^{\circ} 41^{\prime} 56^{\prime \prime} \mathrm{E}$ and latitude of $26^{\circ} 26^{\prime} 2^{\prime \prime} \mathrm{N}$, and terminates at longitude of $67^{\circ}$ $52^{\prime} 2^{\prime \prime} \mathrm{E}$ and latitude of $26^{\circ} 26^{\prime} 2^{\prime \prime} \mathrm{N}$ into the river Indus (Fig. 1). The Danistar Wah is feeding water to a network of about 31 smaller size natural channels (phats), and an area of nearly 51,000 acres is being cultivated through the Wah waters.

Mehran University Research Journal of Engineering \& Technology, Volume 37, No. 4, October, 2018 [p-ISSN: 0254-7821, e-ISSN: 2413-7219] 


\subsection{Ground Truthing}

For assessment of cropping pattern, a geo-referenced survey was conducted in the command area of Danastar Wah during Kharif season (August-September) of 2015. The geo-referenced study was conducted by using the Garmin GPS MAP 62S system. To collect the data in an organized and systematic way, a study proforma was developed. The proforma included information on geoposition (longitude and latitude coordinates), UC name, crop type, bare land, water body and human settlement. The proforma was duly filled during the field visits. For land utilization, crop, barren ground, settlements and water, respective samples were collected randomly. Fig. 2 shows the spatial distribution of sampling locations in the command area of Danastar Wah.
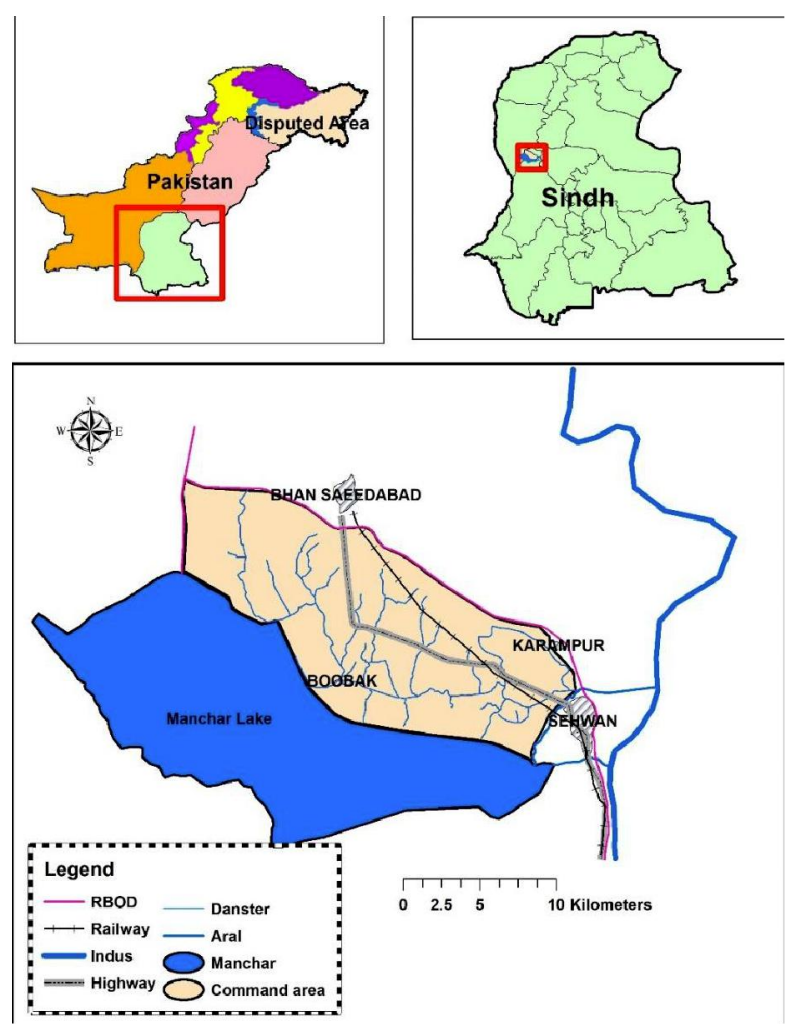

FIG. 1. LOCATION MAP OF DANASTAR WAH AND ITS COMMAND AREA

\subsection{Soil Sampling}

Altogether sixty-three soil samples were collected from twenty-one randomly selected sites of the study area. By using soil augers, the soil samples were taken at depths of 0-20, 20-40 and 40-60 cm. The samples were properly packed and coded with sample numbers, sample depths, coordinates, and dates. All the samples were analyzed for physicochemical properties of soil that included soil texture, the $\mathrm{EC}_{\mathrm{e}}$ of saturated extract, $\mathrm{pH}$, ESP (Exchangeable Sodium Percentage), $\mathrm{CO}_{3}$ (Carbonates), Bicarbonates $\mathrm{HCO}_{3}$ and chlorides $\mathrm{Cl}$. The samples were analyzed at ARI (Agriculture Research Institute), Tandojam, Sindh, Pakistan following US standard procedures documented in a handbook [10].

\subsection{Water Sampling}

Water samples were collected from Manchar Lake, RBOD and from different locations of the Danastar Wah. Water sampling measures were strictly followed by the recommendations made by National Water Quality Monitoring Program [11]. All the water samples were analyzed for their chemical properties, viz. $\mathrm{EC}_{\mathrm{w}}, \mathrm{pH}, \mathrm{CO}_{3}$, $\mathrm{HCO}_{3}, \mathrm{Cl}$, and SAR at ARI, Tandojam.

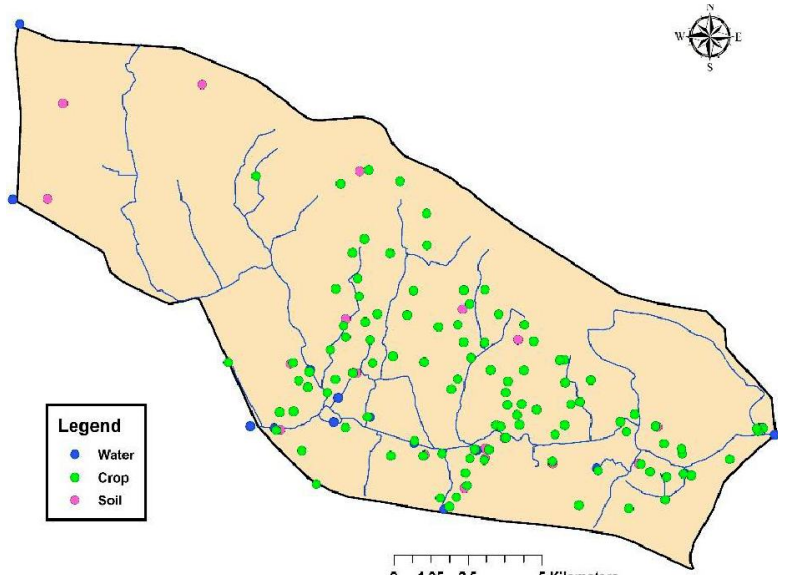

FIG. 2. SOIL, WATER, AND CROP SAMPLING LOCATIONS

Mehran University Research Journal of Engineering \& Technology, Volume 37, No. 4, October, 2018 [p-ISSN: 0254-7821, e-ISSN: 2413-7219] 


\subsection{Satellite Imagery}

\subsubsection{Acquisition and Extraction of Area of Interest}

For monitoring any change on the global surface, Landsat imagery offers reliable dataset [12-14]. For the present study, Landsat 8 imagery (WRS-2 path 152 , row 42, and processing level 1T) was obtained from USGS (United States Geological Survey) portal (http:/ /glovis.usgs.gov). Landsat image for the month of August 2015 (end of Kharif sowing period) was acquired from GloVis for the present study. Other relevant data, such as DOY (Day of the Year), earthsun distance in astronomical units (d) and sun elevation $\left(\theta_{\mathrm{s}}\right)$ were taken from Metafile of the image and Chander et. al. [15]. The DOY, d, and $\theta_{\mathrm{s}}$ for the image were 229, 1.01244 and 64.2677126 respectively. The AOI (Area of Interest) for the command area of Danastar Wah was extracted from the Landsat 8 images obtained from the GloVis using extract by mask tool in Spatial Analyst Toolbox.

\subsubsection{Atmospheric Correction}

The DN (Digital Numbers) of raster image were converted to top of atmospheric reflectance $\left(\mathrm{TOA}_{\mathrm{r}}\right)$ using reflectance rescaling coefficients provided in the product metadata file (MTL file). The relation used to convert DN values to TOA reflectance for OLI data is presentedin Equation (1).

$\rho \lambda^{\prime}=M_{\rho} Q_{c a l}+A_{\rho}$

where, $\rho \lambda$ ' represents the $\mathrm{TOA}_{\mathrm{r}}$ planetary reflectance without correction for a solar angle; $\mathrm{M} \rho$ stands for bandspecific multiplicative re-scaling factor from the metadata which is 0.00002 for bands 1-9 of Landsat $8 ; \mathrm{Q}_{\text {cal }}$ signifies quantized and calibrated standard product pixel values $(\mathrm{DN})$ and $\mathrm{A}_{\rho}$ denotes band-specific additive re-scaling factor from the metadata which is -0.100000 for bands 1-9 for Landsat-8.

The TOA reflectance with correction for sun angle is then formulated as follows in Equation (2):

$\rho \lambda=\frac{\rho \lambda^{\prime}}{\operatorname{Cos}\left(\theta_{\mathrm{SZ}}\right)}=\frac{\rho \lambda^{\prime}}{\operatorname{Sin}\left(\theta_{\mathrm{SE}}\right)}$

where, $\rho \lambda$ represents TOA $A_{\mathrm{r}}$ planetary reflectance, $\theta_{\mathrm{SE}}$ stands for a local elevation angle of the sun, (the scene center sun elevation angle in degrees, provided in the metadata, SUN_ELEVATION), and $\theta_{\mathrm{SZ}}$ denotes local solar zenith angle $\left(\theta_{\mathrm{SZ}}=90^{\circ}-\theta_{\mathrm{SE}}\right)$

\subsubsection{Supervised Classification of Satellite Imagery}

Based on ground truthing samples and signature files for different classes of land utilization, the satellite imagery of Landsat-8 $\mathrm{TOA}_{\mathrm{r}}$ was processed and trained in ArcMap 10.1 software for the study area (Fig. 3). Classified maps of the command area were prepared by using the maximum likelihood classification algorithm. The area covered by each class (i.e. water bodies, crops, bare land, etc.) was computed by converting the raster images into vector polygons.

\subsubsection{Accuracy Assessment}

Accuracy assessment is a necessary step after image classification to check how excellent the image is 
classified. Accuracy assessment of image was carried out to evaluate the classification results while comparing it with ground truthing data of land utilization. One hundred and ten points were taken as test samples in order to get the accuracy and then by presenting these randomly selected points on the classified reference data. These points were given as reference on the basis of guess of their representative class and the results obtained through this method comprised of overall classification Accuracy and Kappa coefficient. The kappa coefficient was calculated by using the relationship in Equation (3):

$\kappa=\frac{\mathrm{p}_{\alpha}-\mathrm{p}_{\varepsilon}}{1-\mathrm{p}_{\varepsilon}}$
Where $\kappa$ is kappa coefficient, $p_{\alpha}$ is the proportion of observations in agreement and $p_{\varepsilon}$ the proportion in agreement due to chance.

\subsubsection{Thematic and Interpolated Spatial Maps}

Based on analysis of water quality data, interpolated thematic maps were prepared for different water quality parameters using graduated symbols. Likewise, soil interpolated spatial maps were also developed for physicochemical properties of the soil using Kriging interpolation tool in ArcMap 10.1.

\section{RESULT DISCUSSION}

Based on analysis of ground truthing field survey and Landsat 8 satellite imagery data, results of the study are discussed in following sub-sections:

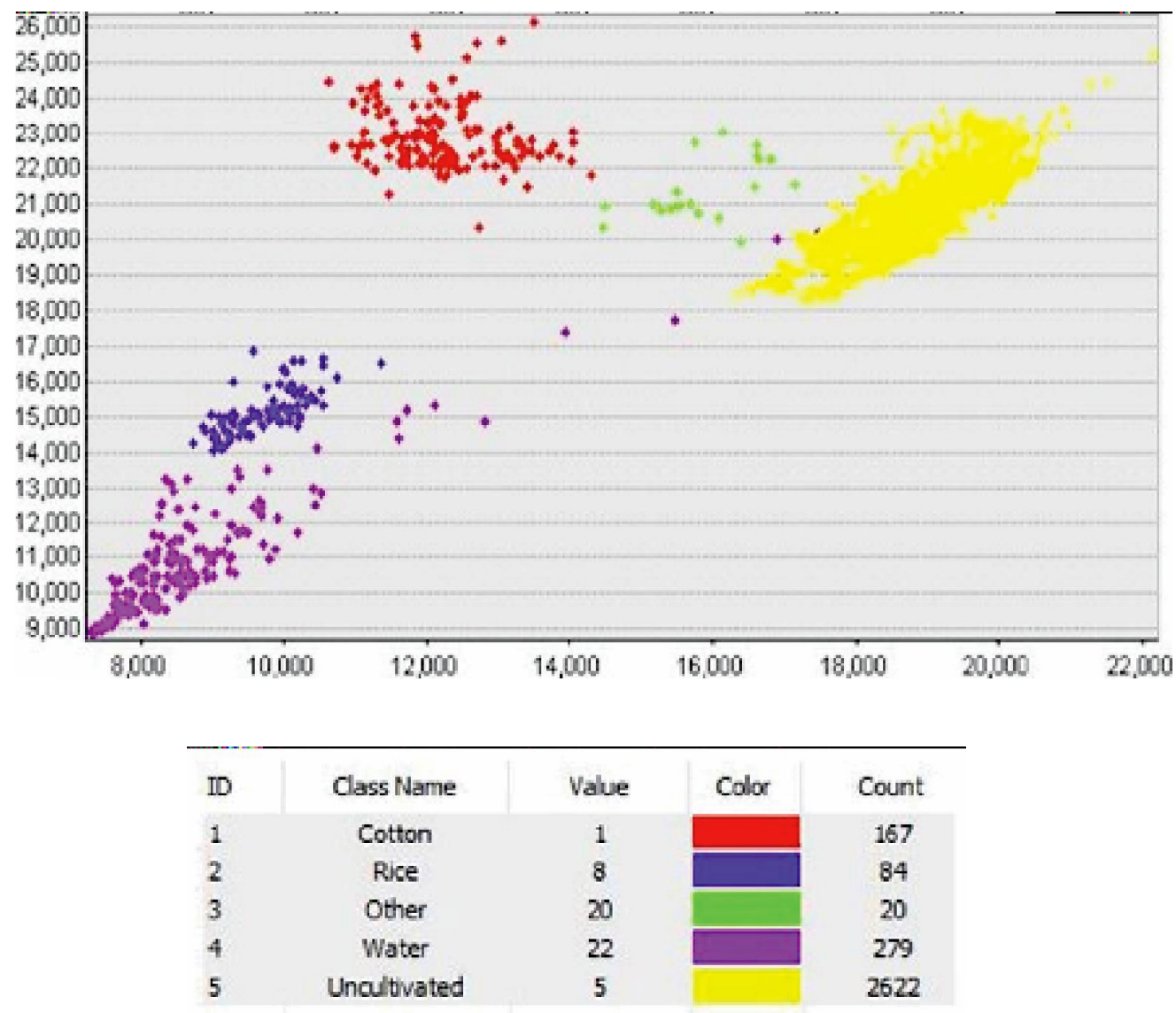

FIG. 3. DISTRIBUTION OF TRAINING DATA IN BANDS 3 AND 1, AND CLASSES OF TRAINING DATA 


\subsection{Water Quality}

Fig. 4(a) presents the thematic map of $\mathrm{EC}_{\mathrm{w}}$ for the water samples collected from the study area (Manchar Lake, RBOD and from various sections of the Danastar Wah). The highest value of $\mathrm{EC}_{\mathrm{w}}=5.5 \mathrm{dS} / \mathrm{m}$ is observed at the confluence of the RBOD with the lake; it may also be noted that the release of RBOD effluent into the lake is the major source of contamination towards the lake. Fig. 4(a) also reveals that the $\mathrm{EC}_{\mathrm{w}}$ value for the Manchar Lake ranges between 1.2-4.5 dS/m. The $\mathrm{EC}_{\mathrm{w}}$ value for Danastar Wah is observed as lesser than $1.2 \mathrm{dS} / \mathrm{m}$ at all its sampling points; hence, the $\mathrm{EC}_{\mathrm{w}}$ for Wah waters is regarded as within the permissible limits $(<1.5 \mathrm{dS} / \mathrm{m})$ [16]. Thus, based on these results it can be concluded that the Wah water is suitable for irrigation purpose. The reason for $\mathrm{EC}_{\mathrm{w}}$ for Wah waters being within the reasonable limits is probably due to a considerable amount of runoff is received from the hill torrents during the monsoon season which mixes with lake water, thereby dilutes it and reduces its $\mathrm{EC}_{\mathrm{w}}$.

The thematic map for $\mathrm{pH}$ value for the water samples collected from the study area (Manchar Lake, RBOD and from various sections of the Danastar Wah) is presented in Fig. 4(b). The pH value of RBOD water ranges between 8.4-8.8. It can be seen from Fig. 4(b) that $\mathrm{pH}$ value of water samples collected from the tail end of the Wah is somewhat higher than the permissible limit of 8.5. The reason for this phenomenon could be the return flow of irrigation waters into the Wah since the Wah lies at a lower elevation than the adjacent agricultural lands.

Any change in sodium percentage is signified by SAR (Sodium Adsorption Ratio). The SAR is the ratio of sodium to calcium and magnesium. Fig. 4(c) presents the thematic map of SAR for the water samples collected from the lake, RBOD and from various locations of the Wah. Though the SAR value for the lake water is slightly higher, yet the water of the lake can be used for irrigation purpose provided adequate drainage be maintained in the area. Continuous use of water with higher SAR value might result in the breakdown of the physical structure of the soil.

The higher contents of $\mathrm{CO}_{3}$ and $\mathrm{HCO}_{3}$ increase the $\mathrm{pH}$ value of water and thereby water tends to become alkaline. In the present study, no any concentration of $\mathrm{HCO}_{3}$ was traced in any of the water samples. Fig. 4(d) presents the thematic map of $\mathrm{CO}_{3}$ concentration in the water samples. The data reveals that the $\mathrm{CO}_{3}$ concentration is within the permissible limits [17].

Excessive concentration of $\mathrm{Cl}$ increases corrosiveness of water and, in combination with sodium, it gives water a salty taste. The thematic map of $\mathrm{Cl}$ concentration for the water samples collected from the study is given in Fig. 5(a). It is obvious that the $\mathrm{Cl}$ concentration in water samples collected from the Manchar Lake and RBOD is more than the permissible limit [16], whereas the $\mathrm{Cl}$ concentration in water samples collected from the Danastar Wah is within the permissible limits.

Fig. 5(b) shows the thematic map of Sodium $(\mathrm{Na})$ ion concentration in the water samples collected from RBOD, Manchar Lake and from different locations of Danister Wah. Fig. 5(b) depicts that Na concentration in all water samples was within the permissible limits (0-40 meq/L) suggested by FAO [16]. Hence, during that period sodium ion concentration in water was not so high to hinder the plant growth. 
Thematic map of $\mathrm{Ca}^{2+}+\mathrm{Mg}^{2+}$ concentration in the water samples is shown in Fig. 5(c). Fig 5(c). depicts that $\mathrm{Ca}^{2+}+$ $\mathrm{Mg}^{2+}$ concentration in all water samples was within permissible limits given by FAO [17]. Usually, calcium and magnesium concentration in water counter the impacts of sodium and help in maintaining good soil properties.

\subsection{Soil Properties}

\subsubsection{Soil texture}

The texture of the soil of the study area was examined from the soil samples collected from various locations in the command area of Danastar Wah. Soil sampling

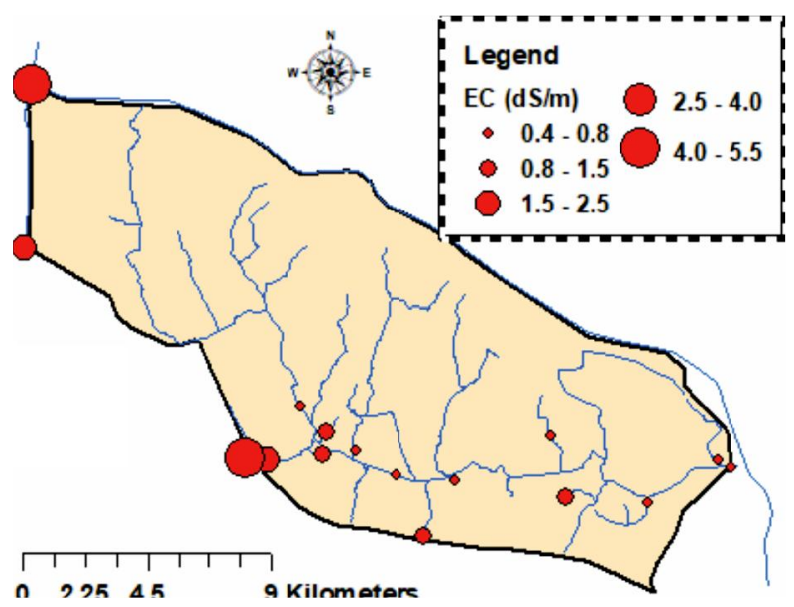

(a) $E C_{w}$

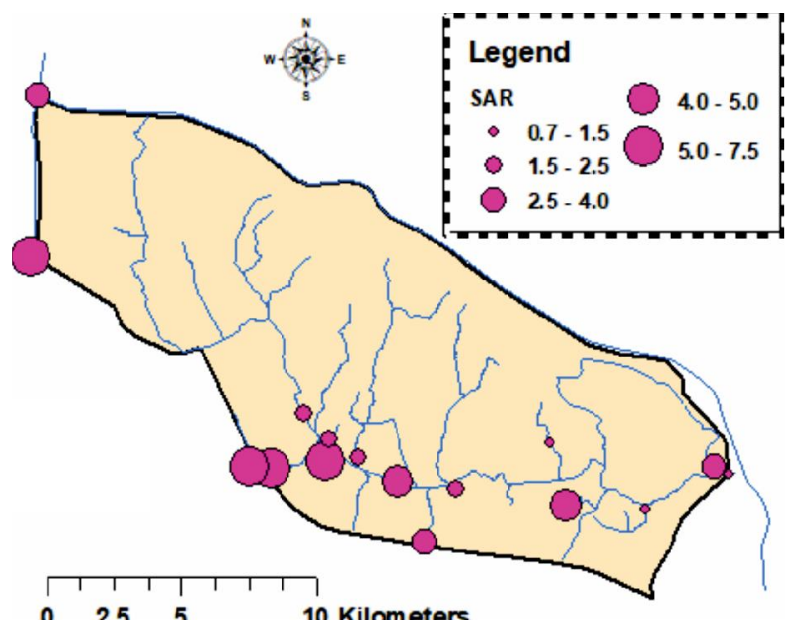

(c) $S A R$ methodology is briefly described in section 2.3 of this manuscript. The results of the soil texture are presented in the shape of spatial mapping (Fig. 6(a-c)).

Significant variation in the texture of the soil profile is observed horizontally as well as vertically downward (depth-wise). Overall results show that the soil texture of the command area comprises of medium to fine textured soil dominated by silt and clay particles. The north-western part of the study area consists of clay soil, while clay loam and silty clay loam soils dominate in rest of the area. Depth-wise, clay was the dominant texture of the soil profile.

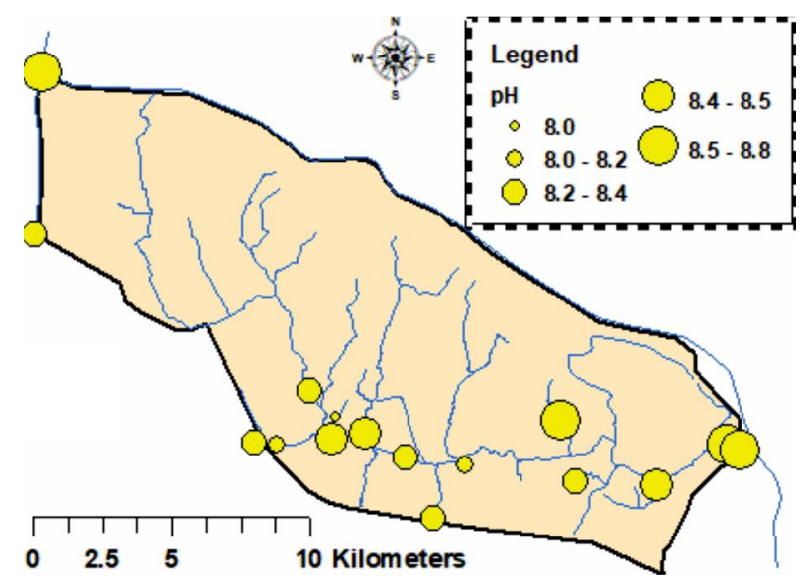

(b) $p H$

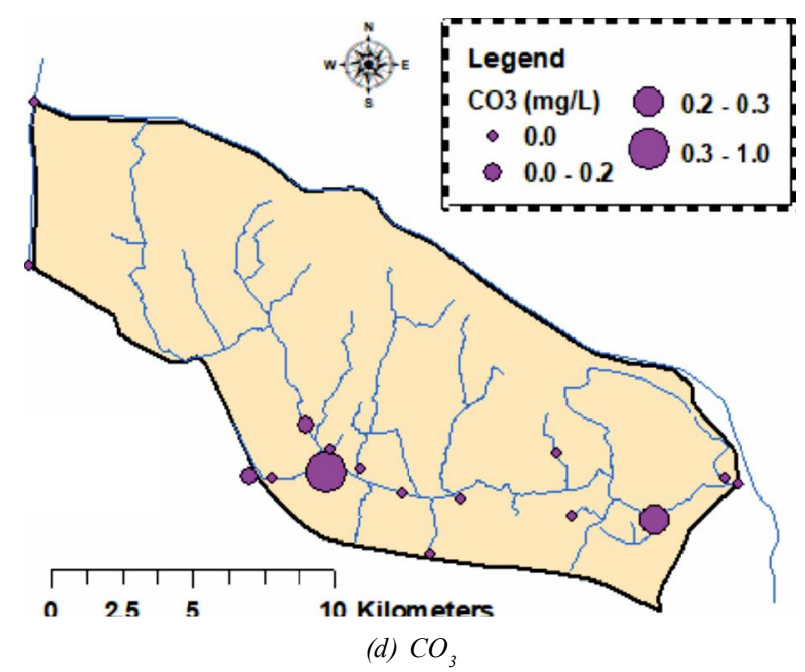

FIG. 4. THEMATIC MAP FOR EC ${ }_{W}$ SAR, AND CO, FOR WATER SAMPLES COLLECTED FROM STUDY AREA 


\subsubsection{Electrical Conductivity}

Fig. 7(a-c) signifies the spatial mapping of variability in soil EC at different depths (0-20, 20-40 and 40-60 cm) of the command area. From Fig. 7, it is evident that a significant part of the command area has EC values smaller than $4 \mathrm{dS} / \mathrm{m}$ throughout the soil profile $(0-60 \mathrm{~cm})$. Higher soil EC values are observed in the areas adjacent to a lake near the eastern boundary of the command area. This might be due to frequent application of irrigation waters by farming community of these localities even when water

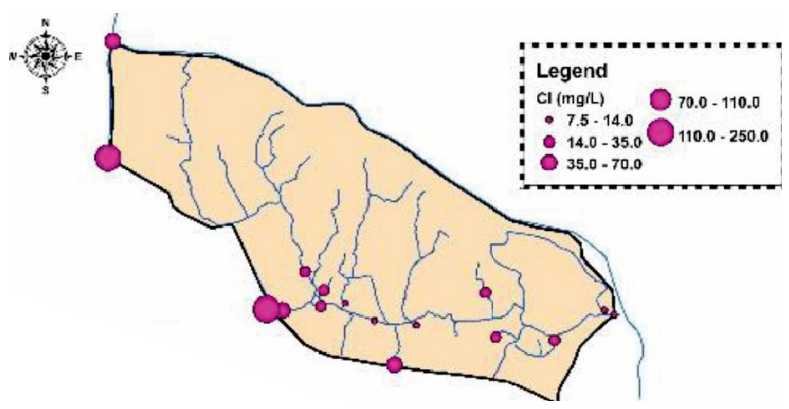

(a) $\mathrm{Cl}$

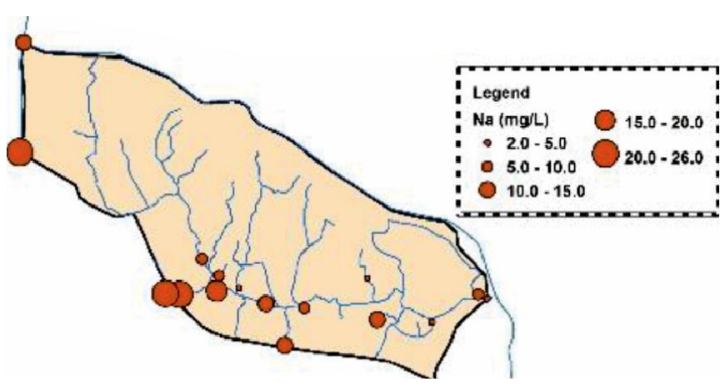

(b) $\mathrm{Na}$

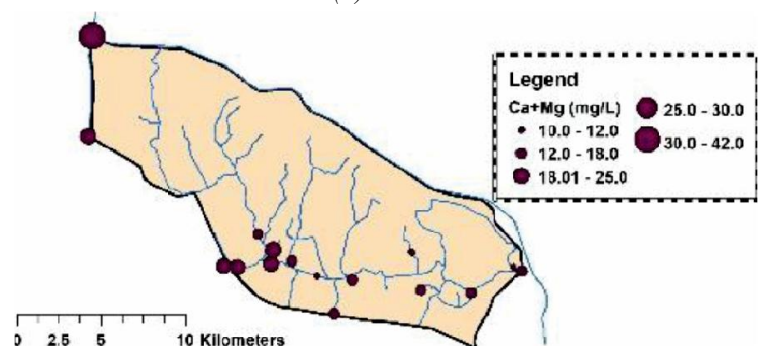

(c) $\mathrm{Ca}^{2+}+\mathrm{Mg}^{2+}$

FIG. 5. THEMATIC MAP FOR Cl, $\mathrm{Na}$, and $\mathrm{Ca}^{2+}+\mathrm{Mg}^{2+} \mathrm{FOR}$ WATER SAMPLES COLLECTED FROM THE STUDY AREA

possesses a higher amount of salts during the winter season. These areas, being closer to Wah and the lake, encourage farmers to apply more frequently irrigation waters.

Fig. 8 presents the percentage of the total command area of the Wah having different levels of soil EC. From Fig. 8, it can be observed that about $40-50 \%$ of the total area have $\mathrm{EC}$ value lesser than $4 \mathrm{dS} / \mathrm{m}$ throughout its soil profile $(0-60 \mathrm{~cm})$; while rest of the command area has moderate EC $(4-12 \mathrm{dS} / \mathrm{m})$ in its entire soil profile $(0-60 \mathrm{~cm})$.

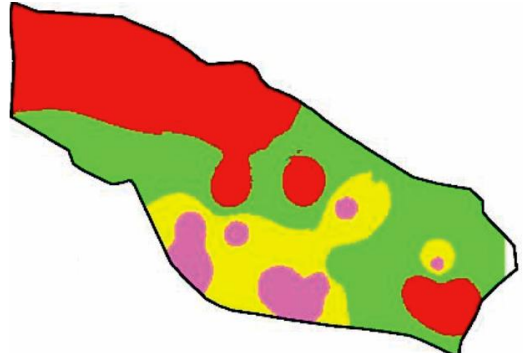

(a) $0-20 \mathrm{~cm}$ SOIL DEPTH

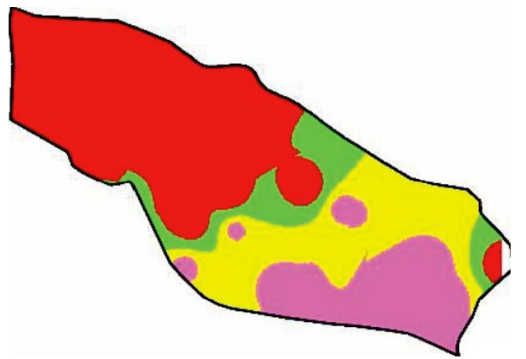

(b) 20-40cm SOIL DEPTH

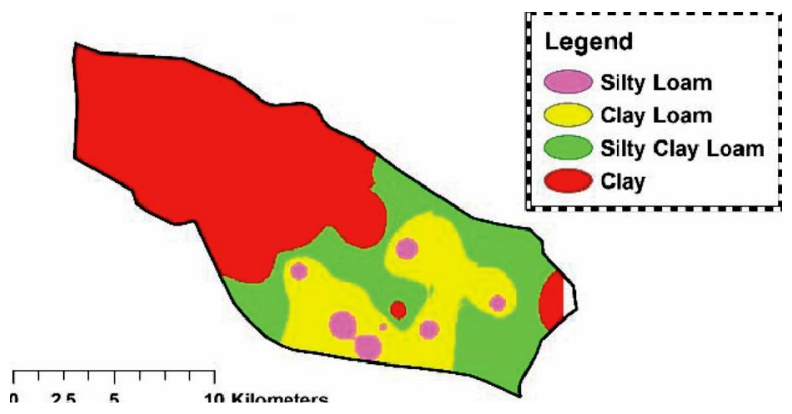

(c) $40-60 \mathrm{~cm}$ SOIL DEPTH

FIG. 6. INTERPOLATED GIS MAP SHOWING SPATIAL DISTRIBUTION OF SOIL TEXTURE

Mehran University Research Journal of Engineering \& Technology, Volume 37, No. 4, October, 2018 [p-ISSN: 0254-7821, e-ISSN: 2413-7219] 


\subsubsection{Soil pH}

Fig. 9(a-c) shows the interpolated maps of the spatial distribution of soil $\mathrm{pH}$ of the command area of Danastar Wah for different soil depths (0-20, 20-40 and 40-60 cm). From Fig. 9, it is obvious that the $\mathrm{pH}$ value of the soil for the entire study area ranges from 8.0-8.8, thus, the soils of the entire study area are recognized as alkaline.

\subsubsection{Soil ESP}

Fig. 10 presents the percentage of total command area of the Danastar Wah under varying degrees of soil ESP at different soil depths $(0-20,20-40$ and 40-60 cm). From Fig.

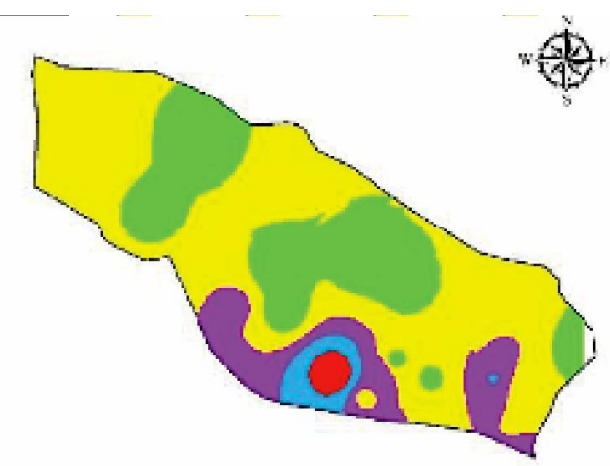

(a) $0-20 \mathrm{~cm}$ SOIL DEPTH

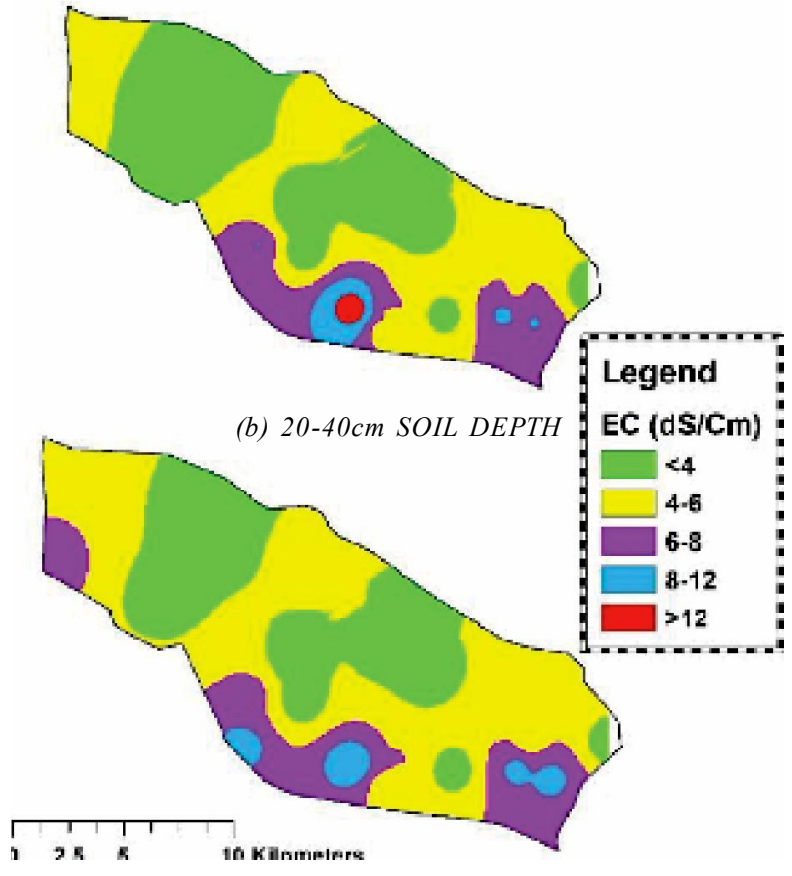

(c) 40-60 cm SOIL DEPTH

FIG. 7. SPATIAL DISTRIBUTION OF SOIL EC
10 , it is seen that more than $80 \%$ of the command area has ESP value within safe limits as per FAO standards [15]; while only smaller part of the study area the ESP value beyond the permissible limits.

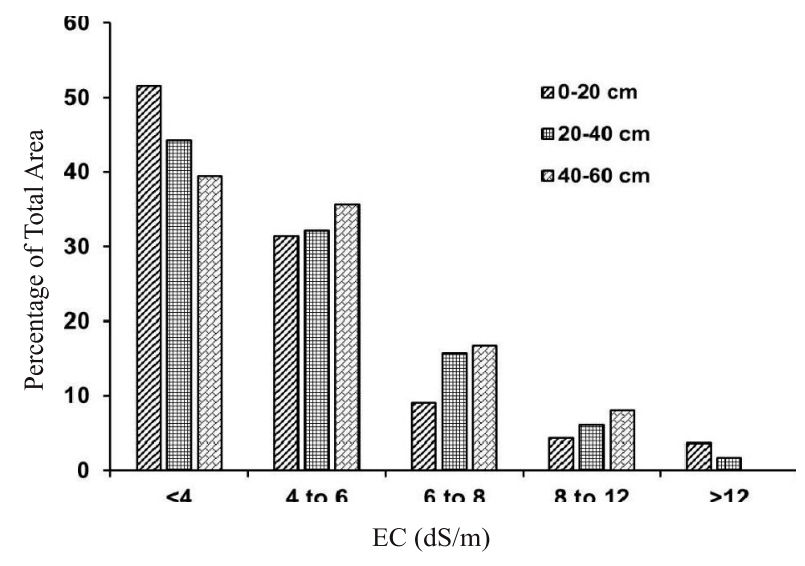

FIG. 8. PERCENTAGE OF TOTAL STUDY AREA WITH VARYING SOIL EC
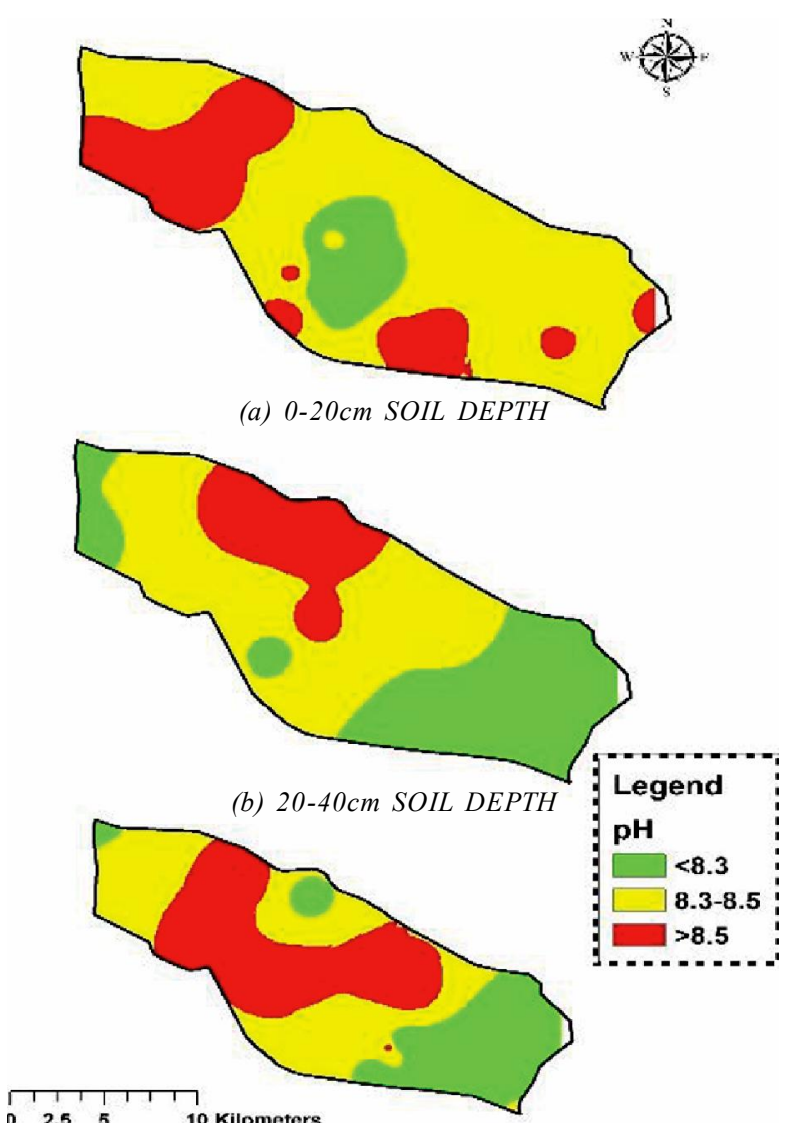

(c) $40-60 \mathrm{~cm}$ SOIL DEPTH

FIG. 9. SPATIAL DISTRIBUTION OF SOIL $\mathrm{pH}$ 
Fig.11(a-c) shows the spatial distribution of the soil ESP in the study area at different soil depths (0-20, 20-40 and 40-60 cm). It can be seen from Fig. 11 that in most of the command area, soil ESP $<15$; while only a smaller part of the area has ESP > 15. Spatial distribution of ESP for the three sampling layers (0-20, 20-40 and 40-60 cm) is almost identical. Hence, depth-wise variability in soil ESP is found as non-significant.

\subsubsection{Soil Salinity}

Fig. 12 displays the percentage of normal, saline, sodic and saline-sodic soils in the command area of the Danastar Wah in the top 0-20 cm soil layer. Results show that about 37,28 , and $30 \%$ of the soils of the command area are normal (non-saline), saline and sodic, respectively; while only $5 \%$ of soils are saline-sodic. Thus, $63 \%$ of land in the Danastar Wah command area is saltaffected. These results highlight the issue of soil salinity and sodicity in the command area of the Danastar Wah.

Fig. 13 presents the spatial distribution of soil salinity in the command area of the Danastar Wah. Results reveal that for the top 0-20 cm layer, apart from the north-eastern area adjacent to RBOD link drain, the area is salt-affected. All the saline-sodic soils are situated along the boundary

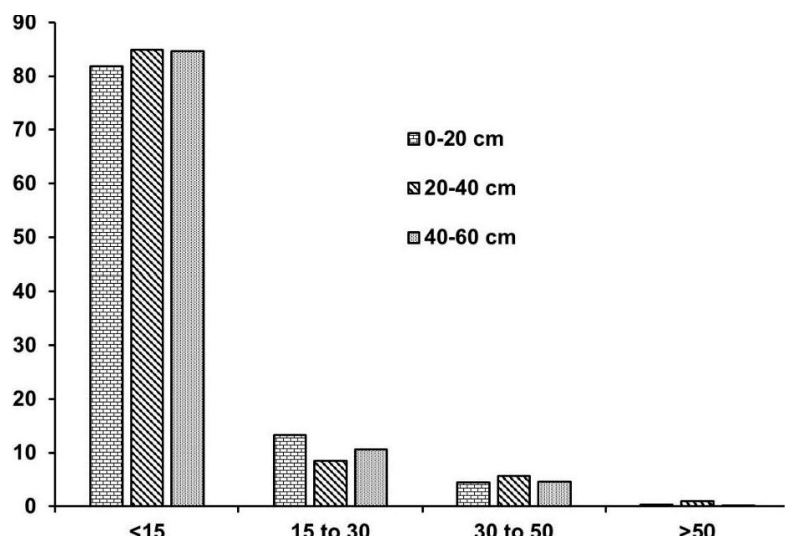

FIG. 10. PERCENTAGE OF TOTAL COMMAND AREA OF THE STUDY AREA WITH DIFFERENT LEVELS OF SOIL ESP of Manchar Lake and near to Bubak city, while rest of the area is saline. Sodic soils are located along the northwestern rim of the command area. Almost similar trend was observed for the bottom layers 20-40 and 40-60 cm depth except increased area under normal soil along the eastern and north-eastern part of the command area.

\subsection{Crop Area Estimation}

Fig 14(a) displays unclassified satellite imagery of the command area of Danastar Wah in pseudo-natural color

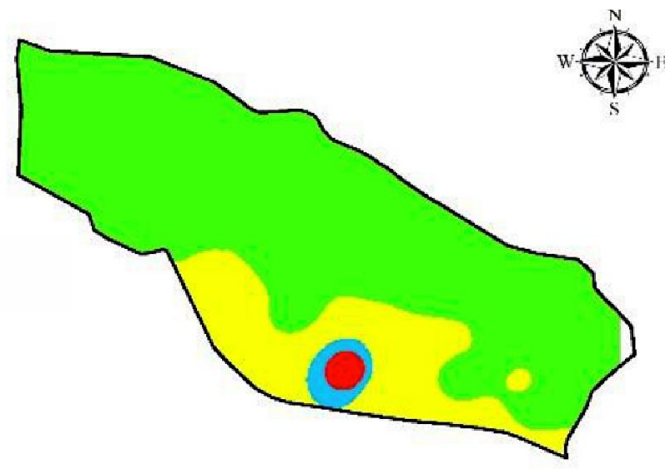

(a) $0-20 \mathrm{~cm}$ SOIL DEPTH

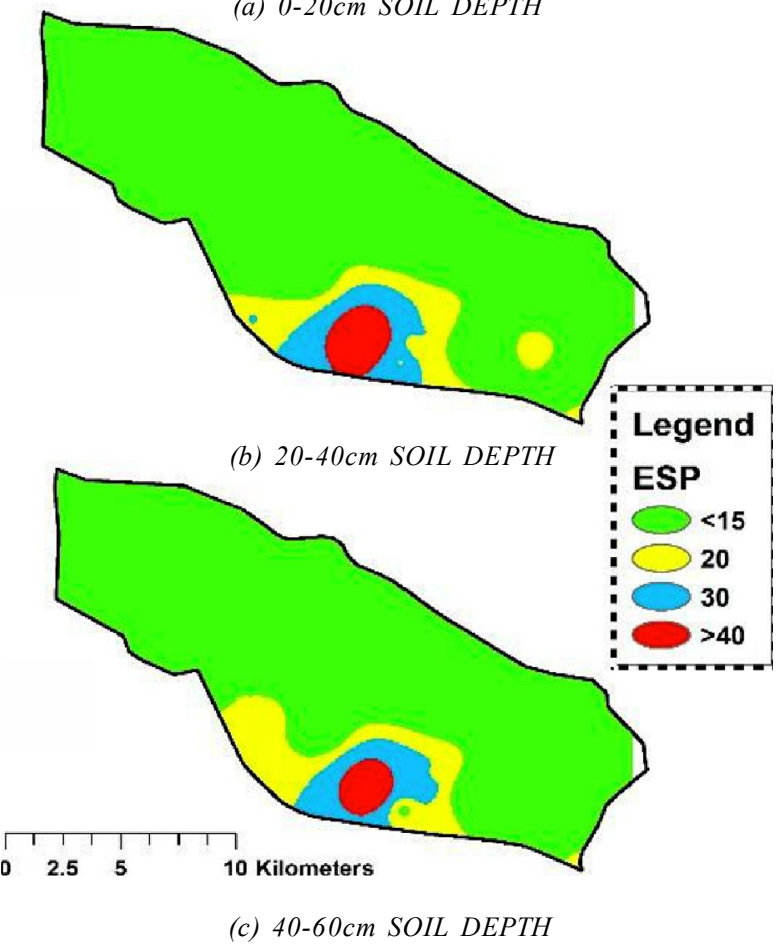

FIG. 11. SPATIAL DISTRIBUTION OF SOIL ESP

Mehran University Research Journal of Engineering \& Technology, Volume 37, No. 4, October, 2018 [p-ISSN: 0254-7821, e-ISSN: 2413-7219] 
which was captured on August 7, 2015, by Landsat 8 Satellite. The Fig. 14(a) shows that the area is sparsely covered with different kinds of crops, while most of the area is uncultivated or barren. Fig. 14(b) shows the classified map of the command area of Danastar Wah. From this map, the areas under major crops, water body, barren land, villages, and towns were quantified that are presented in Table 1. Cotton crop, was identified as the major Kharif crop, which occupied about 2844 ha or $13.76 \%$ of the total command area, followed by rice crop grown on approximately $5.21 \%$ of the command area; about $57.31 \%$ of the command area was occupied by villages, towns, barren land, infrastructure, etc. while water was standing on about $14.83 \%$ of the command area.

\subsection{Accuracy Assessment}

The results of accuracy assessment indicated a high rate of accuracy for the classified image. The user accuracy for the rice, cotton and other vegetation classes was 92.1, 94.4, and 95.0\%, respectively. While producer accuracy was $96.4,94.3$ and $92 \%$ for rice, cotton and other vegetation classes, respectively. Overall accuracy was $90.0 \%$. The kappa coefficient was

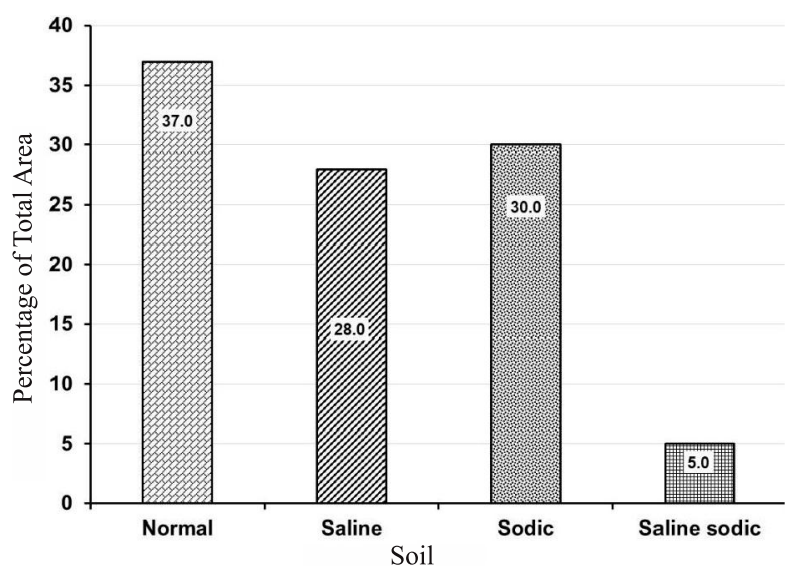

FIG. 12. PERCENTAGE OF TOTAL COMMAND AREA OF THE DANASTAR WAH UNDER NORMAL, SALINE, SODIC AND SALINE-SODIC SOILS

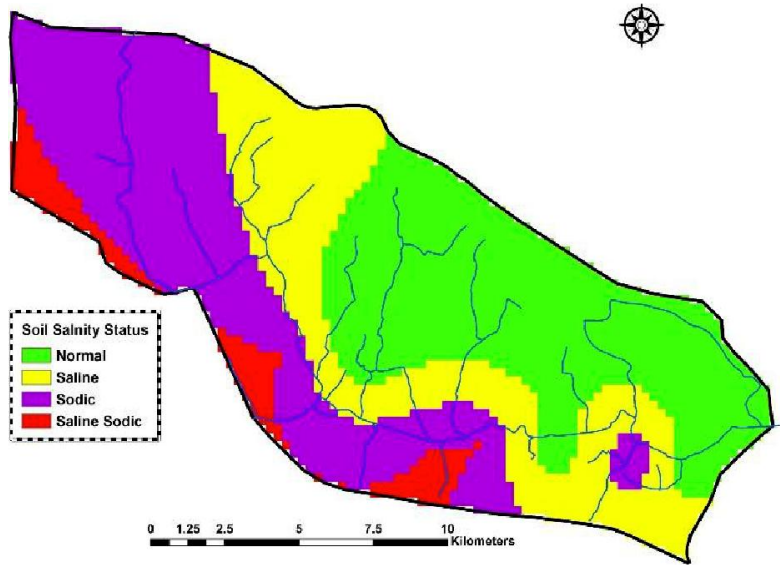

FIG. 13. SPATIAL DISTRIBUTION OF SOIL SALINITY IN THE STUDY AREA
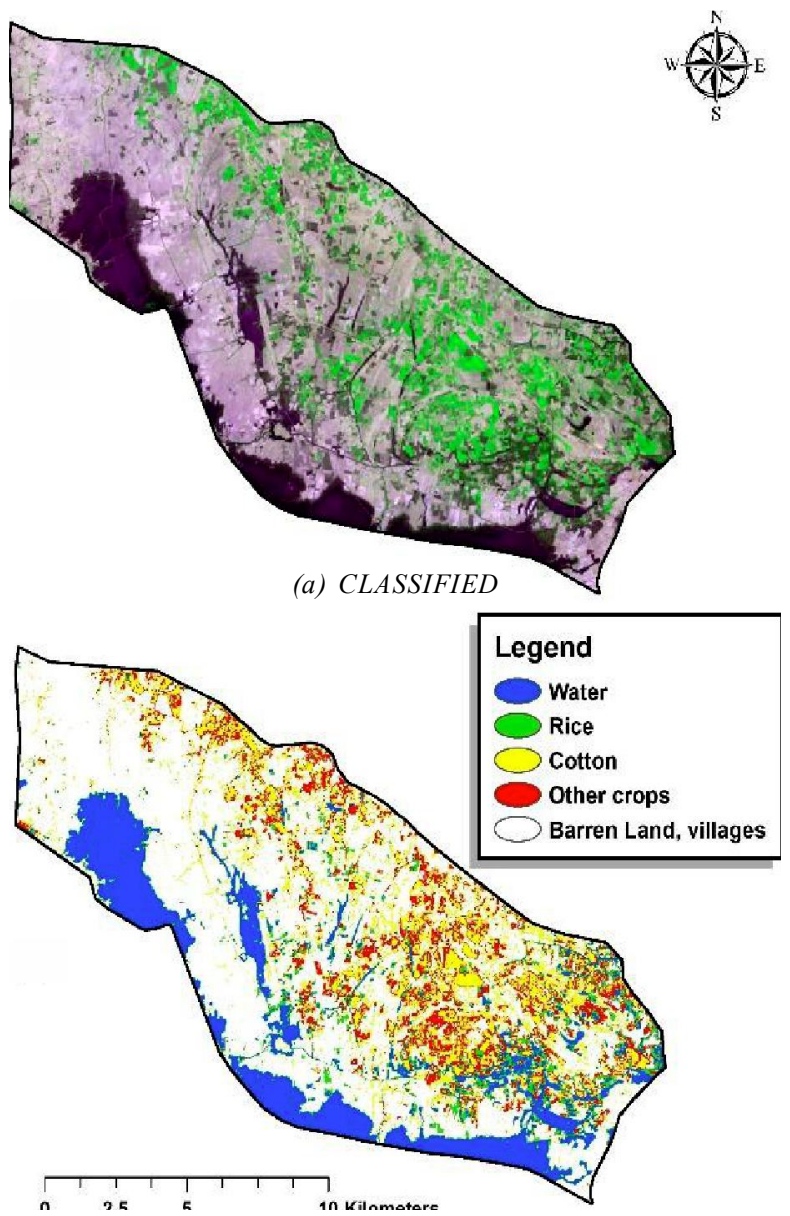

(b) SATELLITE IMAGES OF DANASTAR WAH COMMAND $A R E A$

FIG. 14. UNCLASSIFIED

Mehran University Research Journal of Engineering \& Technology, Volume 37, No. 4, October, 2018 [p-ISSN: 0254-7821, e-ISSN: 2413-7219] 
TABLE 1. LAND UTILIZATION OF THE COMMAND AREA OF DANATAR WAH (AUGUST 7, 2015)

\begin{tabular}{|c|c|c|c|}
\hline No. & Land Utilization & $\begin{array}{c}\text { Area } \\
\text { (ha) }\end{array}$ & Percentage of Total Canal Command Area \\
\hline 1. & Rice & 1,078 & 5.21 \\
\hline 2. & Cotton & 2,844 & 8.78 \\
\hline 3. & Other crops and natural vegetation & 1,835 & 14.83 \\
\hline 4. & Water body & 3,066 & \\
\hline 5. & Towns, villages, uncultivated/bare/saline land, \\
infrastructure, etc. & 11,845 & 57.31 \\
\hline
\end{tabular}

0.86 for the classified image. Lea and Curtis [18] stated that accuracy assessment requires an overall classification accuracy above $90 \%$ and kappa coefficient above 0.80 which were successfully achieved in the present study. Interpretation of kappa indicated that the present study represents almost perfect agreement between user and producer assigned ratings as per Viera and Garrett [19].

\section{CONCLUSION}

The water quality analysis for Kharif season of 2015 reveals that the EC of Manchar Lake and Danastar Wah waters ranges between 1.2-4.5 dS/m, while the EC of RBOD water is as high as $11 \mathrm{dS} / \mathrm{m}$. Thus, it can be concluded that during the Kharif season, the lake water is suitable for irrigation purpose. In all the water samples, $\mathrm{Na}^{+}, \mathrm{Ca}^{2+}+\mathrm{Mg}^{2+}$ and $\mathrm{CO}_{3}$ concentrations are found within the allowable limits, while no concentration of $\mathrm{HCO}_{3}$ is traced in any of the water samples. The texture of the soil comprises of medium to fine, and about 40$50 \%$ of the command area possessed soil EC lesser than $4 \mathrm{dS} / \mathrm{m}$ along its entire profile of $0-60 \mathrm{~cm}$. For most of the command area, the soil ESP is below 15. In the command area of Danastar Wah, about 37, 28, and 30\% of the soils are normal (non-saline), saline and sodic, respectively; while only $5 \%$ of the soils are saline-sodic. Cotton crop, is identified as the major Kharif crop, occupies about $13.76 \%(2,844 \mathrm{ha})$ of the total command area, and this is followed by rice crop grown on about $5.21 \%(1,078 \mathrm{ha})$ of the command area. Until August 7 about $57 \%$ of the total area of the Danastar Wah command area was either uncultivated or bare land or was occupied by roads, towns, villages,etc. Thus, on the basis of the present study, it can be concluded that the Danastar Wah water can be used for irrigation purpose during Kharif season only provided adequate land drainage is maintained. It is also suggested that before using the waters of Manchar Lake, RBOD and Danastar Wah for Rabi cropping, the water quality analysis of these waters be carried out because there is no much chance of fresh water mixing (inflow) into the lake to dilute the waters; thereby, the lake water may not be suitable for irrigation purpose. 


\section{ACKNOWLEDGEMENT}

The authors acknowledge the Institute of Water Resources Engineering \& Management, Mehran University of Engineering \& Technology, Jamshoro, Pakistan, for proving support for accomplishment of the present study.

\section{REFERENCES}

[2] Panhwar, M.H., Soomro, U., Lakho, G.M.,and Soomro, S., "Six Thousand Years of History of Irrigation in Sindh", Department of Culture, Government of Sindh, Karachi, Pakistan, 2011.

Mika, J., Kerenyi, J., Rimoczi-Paal, A., Merza, A., Szinell, C., and Csiszar, I., "On Correlation of Maize and Wheat Yield with NDVI: Example of Hungary (1985-1998)", Advances in Space Research, Volume 30, pp. 2399-2404, 2002

[7] Mkhabela, M.S., Mkhabela, M.N., and Mashinini, N.N., "Early Maize Yield Forecasting in the Four AgroEcological Regions of Swaziland Using NDVI Data from NOAA's-AVHRR”, Agr, Forest Meteorol, Volume 129, pp. 1-9, 2005.
[8] Rojas, O., "Operational Maize Yield Model Development and Validation Based on Remote Sensing and AgroMeteorological Data in Kenya", International Journal of Remote Sensing, Volume 28, pp. 3775-3793, 2007.

[9] Weissteiner, C.J., and Kuhbauch, W., "Regional Yield Forecasts of Malting Barley (Hordeumvulgare L.) by NOAA-AVHRR Remote Sensing Data and Ancillary Data", Journal of Agronomy and Crop Science, Volume 191, pp. 308-320, 2005.

[10] US Salinity Laboratory Staff, "Diagnosis and Improvement of Saline and Alkali Soils", Agric Handbook No 60, USDA, US Govt. Printing Office, Washington DC, 1954.

[11] Kahlown, M.A., Tahir, M.A., and Ashraf, M., "Water Quality Issues and Status in Pakistan”, Proceedings of Seminar on Strategies to Address the Present and Future Water Quality Issues, Pakistan Council of Research in Water Resources, Islamabad, March 6-7, 2002.

[12] Goward, S., Irons, J., Franks, S., Arvidson, T., Williams, D., and Faundeen, J., "Historical Record of Landsat Global Coverage: Mission Operations, NSLRSDA, and International Cooperator Stations", Photogrammetric Engineering and Remote Sensing, Volume 72, pp. 1155-1169, 2006.

[13] Masek, J.G., Vermote, H.C., Wolfe, R., Cohen, W., Hall, F., Kutler, J., and Nelson, P., "North American Forest Disturbance Mapped from a Decadal Landsat Record", Remote Sensing of Environment, Volume 112, pp. 2914-2926, 2008.

[14] Wulder, M.A., White, J.C., Goward, S.N., Masek, J.G., Irons, J.R., Herold, M., Cohen, W.B., Loveland, T.R., and Woodcock, C.E., "Landsat Continuity: Issues and Opportunities for Land Cover Monitoring", Remote Sensing of Environment, Volume 112, pp. 955-969, 2008.

[15] Chander, G., Markham, B.L., and Helder, D.L., "Summary of Current Radiometric Calibration Coefficients for Landsat MSS, TM, ETM+, and EO-1 ALI Sensors", Remote Sensing of Environment, Volume 113, pp. 893-903, 2009. 
[16] Bhumbla, D.R., and Abrol, I.P., "Is Your Water Suitable for Irrigation?", Indian Farming, Volume 22, No. 4, pp. 15-17, 1972.

[17] FAO, "Water Quality for Agriculture", FAO Irrigation and Drainage Paper 29 Rev1, 1994. http://www.fao.org/ DOCREP/003/T0234E/T0234E01.htm\#Ch1.4 (Visited on May 6, 2016).
[18] Lea, C., and Curtis, A.C., "Thematic Accuracy Assessment Procedures: National Park Service Vegetation Inventory, Version 2.0", Natural Resource Report NPS/ 2010/NRR-2010/204, National Park Service, Fort Collins, Colorado, USA, 2010.

[19] Viera, A.J., and Garrett, J.M., "Understanding Interobserver Agreement: The Kappa Statistic", Fam Med, Volume 37, No. 5, pp. 360-363, 2005. 